\title{
A study on parental perception towards children's palliative with special reference to solace thrissur.
}

\author{
Thulasi Sathyan', Kumar Sai Sailesh ${ }^{2}$ \\ ${ }^{1}$ Department of Hospital Administration, Little Flower Institute of Medical Sciences and Research, Angamaly, Kerala, \\ India \\ ${ }^{2}$ Department of Physiology, DM Wayanad Institute of Medical Sciences, Naseera Nagar, Meppadi, Wayanad, Kerala, \\ India
}

\begin{abstract}
The current study was undertaken to observe the effectiveness of children's palliative with special reference to Solace Thrissur. This study mainly considers the 0-18 age group patient's parents to understand the parental perception towards children's palliative. Researcher used 30 samples for collecting data in Thrissur district. Here Simple random sampling is used by researcher, which means that refers to equal chance to be selecting all samples. Questionnaire methods are used for collecting data. Palliative care includes the control of pain and other symptoms and addresses the psychological, social, or spiritual problems of children and their family living with life-threatening or terminal conditions.
\end{abstract}

Keywords: Palliative care, Spiritual problems, Children.

Accepted on 10 January, 2018

\section{Introduction}

In current society, many children are facing various diseases like cancer, stroke, and paraplegia [1]. So the children and their family need many supports like financial, medical, psychological so on. [2] Because some of the family can't extent holistic support to needed the children. So the Solace palliative care at Thrissur gives moral financial support to underprivileged children who is suffering in and out of hospitals by various diseases, solace is mainly focusing the step by step delivering the much needed assistance to those children who are affected with serious and long term illness and alleviates their pain and family suffering.

Many studies were conducted at many countries like Africa, Zimbabwe, curia etc. for the importance and effectiveness of children's palliative care. In Kerala also have children's palliative but there were not many studies about it. So here in this research researcher studying about the effectiveness of children's palliative with special reference to Solace Thrissur [3].

\section{Materials and Methods}

This study mainly considers the $0-18$ age group patient's parents to understand the parental perception towards children's palliative. Researcher used 30 samples for collecting data in Thrissur district. Here Simple random sampling is used by researcher, which means that refers to equal chance to be selecting all samples.

\section{Data collection tool}

Questionnaire methods are used for collecting data.

\section{Pilot study}

A pilot study was conducted with the objectives of ascertaining the feasibility of the scientific study on the topic and also to find out whether the researcher would get suitable samples for carrying on the research. For this the researcher met Palliative workers and children's palliative in Solace Thrissur.

The pre-test has been conducted among the four respondents to see whether any modifications were needed to be made in the data collection tool.

\section{Results}

Results are mentioned in Tables 1-6.

Table 1: Sex wise distribution of respondent.

\begin{tabular}{llll}
\hline SI. No. & Sex & Frequency & Percentage \\
\hline 1 & Male & 18 & $60 \%$ \\
\hline 2 & Female & 12 & $40 \%$ \\
\hline & Total & 30 & $100 \%$ \\
\hline
\end{tabular}

The above table represent that, $60 \%$ of respondent are male, in this study majority of them are male.

Table 2: Age wise distribution.

\begin{tabular}{llll}
\hline SI. No. & Age & Frequency & Percentage \\
\hline 1 & 1 to 5 & 17 & $56.66 \%$ \\
\hline 2 & 6 to 10 & 9 & $30 \%$ \\
\hline 3 & 11 to 15 & 2 & $6.66 \%$ \\
\hline
\end{tabular}




\begin{tabular}{cccc}
\hline 4 & 16 to 18 & 2 & $6.66 \%$ \\
\hline Total & 30 & $100 \%$
\end{tabular}

The above table shows that $56.66 \%$ of children are on the 1 to 5 age group, $30 \%$ are 6 to 10 age group and $6.66 \%$ of children are in 11 to 15 and 16 to 18 age groups. The majority of respondent include in 1 to 5 age group children.

Table 3: Reason for registration.

\begin{tabular}{llll}
\hline SI. No. & Reason for registration & Frequency & Percentage \\
\hline 1 & Cerebral palsy & 10 & $33.33 \%$ \\
\hline 2 & Mentally retarded & 3 & $10 \%$ \\
\hline 3 & Cancer & 3 & $10 \%$ \\
\hline 4 & Bed redden & 2 & $6.66 \%$ \\
\hline 5 & Others & 12 & $40 \%$ \\
\hline & Total & 30 & $100 \%$ \\
\hline
\end{tabular}

The above table shows various disease which registered in children's palliative. The majority children are caused cerebral palsy and $10 \%$ of children are mentally retarded and cancer patients.

Table 4: Duration of disease.

\begin{tabular}{llll}
\hline SI. No & Duration of disease & Frequency & Percentage \\
\hline 1 & By birth & 18 & $60 \%$ \\
\hline 2 & 2 years & 2 & $6.66 \%$ \\
\hline 3 & 3 years & 3 & $10 \%$ \\
\hline 4 & Others & 7 & $23.33 \%$ \\
\hline & Total & 30 & $100 \%$ \\
\hline
\end{tabular}

The above table shows that $60 \%$ of children are suffering various diseases by birth itself, $6.66 \%$ of children are of 2 years. $10 \%$ are of with the duration of 3 years and remain $23.33 \%$ are with various years.

Majority of children include in by birth and least children with the duration of 3 years.

Table 5: Medical history of family members.

\begin{tabular}{llll}
\hline SI. No. & $\begin{array}{l}\text { Does anyone } \\
\text { child's } \begin{array}{c}\text { family } \\
\text { had the disease }\end{array}\end{array}$ & $\begin{array}{c}\text { of the Frequency } \\
\text { member }\end{array}$ & Percentage \\
\hline 1 & Yes & 7 & $23.33 \%$ \\
\hline 2 & No & 23 & $76.66 \%$ \\
\hline & Total & 30 & $100 \%$ \\
\hline
\end{tabular}

The table shows that, $23.33 \%$ of children's family had the disease and $76.66 \%$ children's family members don't had disease.

Table 6: Daily medicines.

\begin{tabular}{llll}
\hline SI. No & Daily medicines & Frequency & Percentage \\
\hline 1 & Yes & 26 & $86.66 \%$ \\
\hline 2 & No & 4 & $13.33 \%$ \\
\hline & Total & 30 & $100 \%$ \\
\hline
\end{tabular}

This table represents the number of children taking daily medicine or not. The majority are using daily medicines due to their disease.

\section{Discussion}

Findings are a systematic investigation to establish facts or principles or to collect information on the topic on the effectiveness of children's palliative with special reference top Solace Thrissur.

The majority of the children are in the age group of 1-5. The majority $(60 \%)$ patients are male, female patients are not interested to come palliative. Solace palliative is providing recreation activities, majority of the children are not participating, but some of them are participating, these help them to get recreation, refreshment. Many of the fathers are avoiding the patients and their mother because of the illness of the children. Majority of respondents communicate their financial problem with the palliative volunteers. All (100\%) of the respondents are satisfied from palliative services. Mainly the homecare services are provided for the severe cases that do not have the ability to do their basic and daily activities. Solace palliative is providing medically, socially, financial support to the patients. The majority $(30 \%)$ patients come to palliative care under the suggestion of some members and $20 \%$ of members are come under the suggestion of particular doctor a person who suffering many kind of diseases with poor economy. The doctor is sent them to Solace palliative care for getting services from the side of palliative. $100 \%$ respondents are satisfied in palliative workers. While parents visiting the Solace palliative they mostly discussed about the current situation of the children, improvements, medical expenses, financial capacity, etc. The majority of parents visited the palliative once in a month. The majority of patients need above 3000 for their medical expenses in a month. Palliative was aware about the financial background of the patients.

Majority children are uneducated because they can't attend the school due to their diseases.

The majority (56.66\%) affected cerebral palsy and $10 \%$ of them are affected cancer and mentally retarded. The majority $(86.66 \%)$ of children are taking daily medicines for their diseases. Solace palliative is providing ration support to very poor family who can't earn for their livelihood. Every respondent have no suggestion about the palliative services because they were satisfied in the services of palliative. The minority $(40 \%)$ children get help from others help such as, from relatives, religious institution, neighbours etc. The majority $(63.33 \%)$ respondent are satisfied in both hospital services as well as palliative services. Some of the parents wish to get physiotherapy treatment from Solace. 
Citation: Sathyan/Sai Sailesh. A study on parental perception towards children's palliative with special reference to solace thrissur. J Biochem Biotech. 2018;1(1):52-54.

\section{Conclusion}

A child is a homosapien between the stages of birth and puberty. Many children affect many kind of diseases, palliative care for children living with a life-threatening or terminal condition. Advice on the development of a palliative care plan and on working with parents and children is also provided. Barriers to the provision of effective children's palliative care and potential solutions are identified.

For children living with life threatening or terminal conditions, medical technology are used only when the benefits from palliative care when no treatment has been shown to alter substantially the expected progression towards death. Palliative care seeks to enhance quality of life in the face of an ultimately terminal condition. Palliative treatments focus on the relief of symptoms and conditions that causes distress and detract from the child's enjoyment of life. It also seeks to ensure that bereaved families are able to remain functional and intact [4-10].

Palliative care includes the control of pain and other symptoms and addresses the psychological, social, or spiritual problems of children and their family living with life-threatening or terminal conditions [11-14]. The goal of palliative care is the achievement of the best quality of life for patients and their families, consistent with their values, regardless of the location of the patient [3].

\section{References}

1. Santha S. Impact of Pain and Palliative Care Services on Patients. Indian J Palliat Care. 2011;17(1):24-32.

2. Jodi Lemacks, Kristin Fowles, Amanda Mateus, et al. Insights from Parents about Caring for a Child with Birth Defects. Int J Environ Res Public Health. 2013;10(8): 3465-82.

3. Stephen Liben, Danai Papadatou, Joanne Wolfe. Paediatric palliative care: Challenges and emerging ideas. The Lancet. 2008;371:852-64.

4. Hinds PS, Brandon J, Allen C. Patient-reported outcomes in end-of-life research in pediatric oncology. J Pediatr Psychol. 2007;32;1079-88.

5. Weaver MS, Heinze KE, Bell CJ, et al. Establishing psychosocial palliative care standards for children and adolescents with cancer and their families: An integrative review. Palliat Med. 2016;30:212-23.

6. Rosenberg AR, Oreliana L, Ullrich C. Quality of life in children with advanced cancer: A Report from the
PediQUEST Study. J Pain Symptom Manag. 2016;52:243-53.

7. Fromme EK, Eilers KM, Mori M, et al. How accurate is clinician reporting of chemotherapy adverse effects? A comparison with patient-reported symptoms from the Quality-of-Life Questionnaire C30. J Clin Oncol. 2004;22:3485-90.

8. Basch E. The missing voice of patients in drug-safety reporting. N Engl J Med. 2010;362:865-9.

9. Collins JJ, Devine TD, Dick GS, et al. The measurement of symptoms in young children with cancer: The validation of the Memorial Symptom Assessment Scale in children aged 7-12. J Pain Symptom Manag. 2002;23:10-6.

10. Chang PC, Yeh CH. Agreement between child self-report and parent proxy-report to evaluate quality of life in children with cancer. Psycho-Oncology. 2005;14:125-34.

11. Panepinto JA, Hoffmann RG, Pajewski NM. The effect of parental mental health on proxy reports of health-related qualify of life in children with sickle cell disease. Pediatr Blood Cancer. 2010;55:714-21.

12. Varni JW, Seid M, Rode CA. The PedsQL: Measurement Model for the Pediatric Quality of Life Inventory. Med Care. 1999;37:126-39.

13. Mandrell B, Baker J, Levine D, et al. Children with minimal chance for cure: Parent proxy of the child's health-related quality of life and the effect on parental physical and mental health during treatment. J Neurooncol. 2016;129:373-81.

14. Bland JM, Altman DG. Measuring agreement in method of comparison studies. Stat Methods Med Res. 1999;8:135-60.

\section{*Corresponding author}

Kumar Sai Sailesh

Assistant Professor,

Department of Physiology,

DM Wayanad Institute of Medical

Sciences, Naseera Nagar,

Meppadi, Wayanad, Kerala,

India

E-mail: Saisailesh.kumar@gmail.com 